\title{
Komparasi Konsep Sosiokulturalisme dalam Pendidikan: Perspektif Barat dan Islam
}

\author{
Nia Indah Purnamasari \\ Sekolah Tinggi Agama Islam YPBWI Surabaya \\ Email: iendha.nyax@gmail.com
}

\begin{abstract}
Abstrak
Tulisan ini menguraikan kerangka konseptual sosiokulturalisme pendidikan Barat yang direpresentasikan oleh Lev Vygotsky. Kerangka tersebut menekankan pada pentingnya interaksi sosial bagi perkembangan belajar anak didik. Pengembangan berlangsung seiring dengan perubahan-perubahan yang ada di lingkungan sosialnya, sehingga akan membentuk kepribadian mereka. Kosepsi ini memiliki kesamaan dengan pendidikan Islam dalam proses pembelajaran, yaitu sama-sama memandang bahwa interaksi sosial dan budaya merupakan hal penting yang harus diperhatikan dalam proses pembelajaran, karena hal itu dapat mempengaruhi perkembangan kepribadian dan pola pikir individu dalam proses pembelajaran. Sedangkan perbedaan di antara keduanya, yaitu konsep sosiokulturalisme dalam pendidikan Barat lebih menekankan pentingnya interaksi sosial dalam proses pembelajaran bagi perkembangan belajar seseorang. Proses tersebut tanpa tujuan akhir kecuali untuk membentuk tingkatan kognitif yang lebih tinggi dan mengalir sejalan dengan perubahan yang ada di lingkungannya. Sedangkan dalam pendidikan Islam lebih menekankan pada keseimbangan antara duniawi dan ukhrawi. Dengan kata lain, di samping memperhatikan subjek-subjek kebudayaan, latihan-latihan praktis dan pemikiran, pendidikan Islam mengutamakan pembinaan semangat dan sikap keagamaan.
\end{abstract}

Kata Kunci: Pendidikan Islam, Sosiokulturalisme, Interaksi Sosial, Sikap Keagamaan

\section{Pendahuluan}

Peserta didik adalah manusia yang memiliki identitas sebagai subyek berkesadaran perlu ditegaskan melalui pendekatan-pendekatan dalam pendidikan yang mampu menjawab berbagai persoalan kehisupan sosial. Pandangan yang lebih mampu mengakomodasi tuntutan tersebut adalah teori belajar yang dikembangkan oleh Vygotsky. Peningkatan fungsifungsi mental seseorang berasal dari kehidupan sosial, bukan sekedar dari individu itu sendiri. ${ }^{1}$ Teori Vygotsky, sebenarnya lebih tepat disebut

${ }^{1}$ Olga Esteve, Francesc Fernández, Asunción Bes,"Pre-service Teacher Education from a Sociocultural Perspective: A Case-Study on Teaching Learning through 
sebagai pendekatan konstruktivisme. ${ }^{2}$ Salah satu konsep dasar pendekatan konstruktivisme dalam belajar adalah adanya interaksi sosial individu dan lingkungannya. Pengetahuan yang telah ada sebagai hasil dari proses elemen dasar ini akan lebih berkembang ketika mereka berinteraksi dengan lingkungan sosial budaya mereka. ${ }^{3}$ Oleh karena itu, Vygotsky sangat menekankan pentingnya peran interaksi sosial bagi perkembangan belajar seseorang. ${ }^{4}$

Teori Vygotsky merupakan salah satu teori dalam psikologi perkembangan. Teori Vygotsky menekankan pada hakekat sosiokultural dari pembelajaran. ${ }^{5}$ Teori ini menekankan tentang kebudayaan sebagai faktor penentu bagi perkembangan individu. Diyakini bahwa hanya manusia yang dapat menciptakan kebudayaan, dan setiap anak manusia mampu berkembang dalam kontek kebudayaannya. Kebudayaan memberikan dua kontribusi terhadap perkembangan intelektual anak. Pertama, anak memperoleh banyak sisi pemahamannya dan kedua anak memperoleh banyak cara berpikir atau alat adaptasi intelektual. ${ }^{6}$ Implikasi dari wawasan Vygotsky adalah budaya yang berbeda mungkin mempunyai metal sharing yang berbeda pula, dan konsekuensinya adalah mentransmisikan kesadaran yang juga berbeda. ${ }^{7}$

Berdasar teori Vygotsky, maka dalam kegiatan pembelajaran hendaknya anak memperoleh kesempatan luas untuk mengembangkan zona proksimalnya atau potensinya melalui belajar berkembang. Guru perlu menyediakan berbagai jenis dan tingkatan bantuan yang dapat memfasilitasi anak agar mereka dapat memecahkan permasalahan yang dihadapinya. Bantuan dapat berupa contoh, pedoman, bimbingan orang lain atau teman yang lebih kompeten. Sedangkan anak yang telah mampu belajar sendiri perlu ditingkatkan tuntutannya, sehingga tidak perlu

Conceptual Mediation", Journal of Language and Sociocultural Theory, Vol. 5, No. 2 (2018).

${ }^{2}$ Asri Budi Ningsih, Belajar dan Pembelajaran (Jakarta: Rineka Cipta, 2005), 106.

3 Elene Bodrova, "Key Concepts of Vygotsky's Theory of Learning and Development", Journal of Early Childhood Teacher Education, Vol. 18, No. 2 (1997).

${ }^{4}$ Baharudin dan Esa Nur Wahyuni, Teori belajar dan Pembelajaran (Yogyakarta : Arruz Media, 2007), 124.

${ }^{5}$ Trianto, Model Pembelajaran Terpadu dalam Teori dan Praktek (Jakarta : Prestasi Pustaka, 2007), 29.

6 Syamsul Yusuf, Psikologi Perkembangan Anak dan Remaja (Bandung : Remaja Rosdakarya, 2005), 7.

7 Singgih D. Gunarsa, Dari Anak Sampai Usia Lanjut (Jakarta : BPK Gunung Mulia, 2004), 75. 
menunggu anak yang berada di bawahnya. ${ }^{8}$ Dengan demikian, diperlukan pemahaman yang tepat tentang karakteristik siswa dan budayanya sebagai pijakan dalam pembelajaran.

Pendidikan Islam sebagai interaksi antara budaya menurut Langgulung sangat terkait dengan konsep fitrah. Fitrah dapat dipandang dari dua sisi yaitu fitrah sebagai potensi yang melengkapi manusia sejak lahir dan fitrah sebagai din yang menjadi tiang tegaknya peradaban Islam. Kedua hal tersebut bagaikan dua sisi mata uang yang tidak dapat dipisahkan, pendidikan yang baik akan memberikan sumbangan pada semua bidang pertumbuhan individu. ${ }^{9} \mathrm{Di}$ sisi lain, pendidikan Islam bila dilihat dari segi kehidupan kultural umat manusia tidak lain adalah merupakan salah satu alat pembudayaan (enkulturasi) masyarakat manusia itu sendiri. Sebagai suatu alat pendidikan seperti difungsikan untuk mengarahkan pertumbuhan dan perkembangan hidup manusia, (sebagai makhluk pribadi dan sosial) kepada titik optimal kemampuannya untuk memperoleh kesejahteraan hidup di dunia dan kebahagiaan hidup di akhirat. ${ }^{10}$ Dengan kata lain untuk merumuskan tujuan pendidikan Islam, yaitu dengan mengetahui terlebih dahulu ciri manusia sempurna menurut Islam, yaitu dengan mengetahui terlebih dahulu hakekat manusia menurut Islam. ${ }^{11}$

Dengan demikian, kita perlu mengkaji ulang konsepsi sosiokultural Vygotsky dengan mengkomparasikan dengan konsepsi dasar pendidikan Islam sebagaimana yang terdapat dalam al-Qur'an dan Hadith. Dengan harapan nantinya dapat mengetahui korelasi antara konsepsi sosiokultural Vygotsky dengan konsepsi dasar pendidikan Islam yang sama-sama memperhatikan pendidikan dari segi lingkungan sosial budaya dan supaya menjadi landasan dan pegangan dalam proses belajar dan pembelajaran.

\section{Teori dan Konsep Pendidikan Vygotsky}

Lev Vygotsky adalah teorisi utama yang sangat menghargai dayadaya developmentalis dan environmentalis di wilayah teori perkembangan kognitif. Tepatnya seorang pemikir Rusia yang juga merupakan seorang marxis yang percaya bahwa kita bisa memahami

${ }^{8}$ Elena Bodrova \& Deborah J. Leong, "Vygotskian and Post-Vygotskian Views on Children's Play”, American Journal of Play, Vol. 7, No. 3 (2015).

${ }^{9}$ M. Suyudi, Pendidikan dalam Perspektif Al-Qur'an (Yogyakarta : Mikraj, 2005), 262.

${ }^{10}$ M. Arifin, Ilmu Pendidikan Islam (Jakarta: Bumi Aksara, 1993), 12.

11 Ahmad Tafsir, Ilmu Pendidikan dalam Perspektif Islam (Bandung: Remaja Rosdakarya, 1994), 34. 
manusia hanya dalam konteks lingkungan yang sosial historis. Karena itu, Vygotsky berusaha menciptakan sebuah teori yang memadukan dua garis utama perkembangan "garis alamiah" yang muncul dari dalam diri manusia, dan garis "social historis" yang mempengaruhi manusia sejak kecil tanpa bisa dihindari. Sebuah pandangan hidup Vygotsky dalam menghasilkan karya-karyanya tidak lepas dari pengaruh beberapa teori. ${ }^{12}$ Setelah Vygotsky membaca tulisan-tulisan awal Gesell, Werner dan Piaget, dia menyadari pentingnya jenis-jenis perkembangan intrinsik yang mereka temukan itu. Namun, pada saat yang sama, Vygotsky adalah seorang yang marxis yang percaya bahwa kita bisa memahami manusia hanya dengan konteks lingkunagan sosial dan histories. Karena itu Vygotsky berusaha menciptakan sebuah teori yang memadukan dua garis utama perkembangan yaitu "garis alamiah"yang muncul dari dalam diri manusia, dan garis "sosial historis" yang mempengaruhi manusia sejak kecil. ${ }^{13}$

Selain itu, Vygotsky mengemukakan pengetahuan dan perkembangan kognitif individu berasal dari sumber-sumber sosial diluar dirinya, hal ini tidak berarti bahwa individu bersikap positif dalam perkembangan kognitifnya, tetapi Vygotsky juga menekankan pentingnya peran aktif seseorang dalam mengkonstruksi pengetahuan. Maka teori Vygotsky sebenarnya lebih tepat disebut dengan pendekatan kokontrukvisme. Maksudnya perkembangan kognitif seseorang di samping ditentukan oleh individu sendiri secara aktif, juga oleh lingkungan sosial yang aktif pula. ${ }^{14}$ Sedangkan Suparno, membedakan dua tradisi besar dari konstruktivisme, yaitu konstruktivisme psikologis sosiologi. Konstruktivisme sosial lebih menekankan kepada masyarakatlah yang membangun pengetahuan. Konstruktivisme psikologi bercabang dua yaitu yang lebih personal (Piaget) dan yang lebih sosial (Vygotsky). Sedangkan Konstruktivisme sosial berdiri sendiri. ${ }^{15}$ Teori pembudayaan sosial atau juga dikenali sebagai teori konstruktivisme sosial telah diperkenalkan oleh Lev Semenovich Vygotsky. Ia menulis

${ }^{12}$ Marta Topçiu, "Vygotsky Theory on Social Interaction and its Influence on the Development of Pre-School Children", European Journal of Social Sciences Education and Research, Vol. 2, No. 3 (May-August 2015).

${ }^{13}$ Willam Crain, Teori Perkembangan; Konsep dan Aplikasi (Yogyakarta: Pustaka Pelajar, 2007), 334.

14 Lihat, Sri Wulandari Danoebroto, "Teori Belajar Konstruktivis Piaget dan Vygotsky", Indonesian Digital Journal of Mathematics and Education, Vol. 2 No. 3 (2015).

${ }^{15}$ Paul Suparno, Filsafat Konstruktivisme dalam Pendidikan (Yogyakarta: Kanisius, 2006), 41. 
buku tentang, "pemikiran dan bahasa" dan "fikiran masyarakat". Keduanya telah diterjemahkan dan diterbitkan semula di Barat. Vygotsky percaya bahwa pembelajaran dan perkembangan adalah suatu kegiatan sosial, yaitu aktifitas kerja sama. Pengalaman dan pengetahuan tidak harus dipisahkan tetapi sebaliknya pengalaman di luar sekolah haruslah menjadi berhubungan dengan pengalaman di dalam sekolah. ${ }^{16}$

Dalam teori ini, bahasa yang digunakan selama interaksi memainkan peranan yang amat penting sebagai alat komunikasi dalam membina pengetahuan dan pengalaman. Model kognitif yang diwakili oleh Piaget, Bruner dan Vygotsky, sangat tepat digunakan. Model ini adalah pandangan terbaru mengenai perolehan bahasa pada anak-anak ialah pandangan yang disebut proses model. Inti dari pendekatan ini adalah suatu model kognitif untuk bahasa, yang mencoba menjelaskan bagaimana bahasa itu diproses secara kognitif dan bagaimana manifestasinya dalam tingkah laku. Scaffolding sebagai suatu proses di mana siswa dibantu untuk memahami suatu masalah tertentu yang melebihi perkembangan mentalnya melalui bantuan seorang guru atau orang yang memahaminya. Konsep Scaffolding Buner mirip dengan Zona perkembangan terdekat Vygotsky. Menurut Vigotsky memberikan bantuan selama tahap-tahap awal belajar dan kemudian sedikit demi sedikit menghilangkan bantuan dan memberikan anak tersebut meningkatkan tanggung jawabnya. ${ }^{17}$

Menurut Vygotsky, kegiatan mental juga akan lebih mudah jika ada alat pendukungnya. Yang ia sebut sebagai tool of the mind yang berfungsi untuk mempermudah anak untuk memahami suatu fenomena, memecahkan masalah, mengingat dan berfikir. Sebagai contoh, batu, manik-manik, atau lidi merupakan alat yang dapat membantu anak memahami konsep bilangan. Anak dapat meng hubungkan benda tersebut dengan bahasa simbol seperti "satu, dua, tiga" dan seterusnya. ${ }^{18}$ Vygotsky begitu terkesan oleh tulisan Engels mengenai penggunaan alat, dan dia berusaha mengembangkan inspirasi-inspirasi Engels yang mengatakan bahwa kemampuan manusia telah berubah sebagi hasil dari perkembangan sejarah khususnya perkembangan teknologis.

Namun, seiring perkembangan alat-alat baru oleh spesies kita untuk menghadapi lingkungan, manusia menjadi lebih sadar akan sifatsifat objek, mengembangkan cara-cara baru untuk bekerja sama dengan berkomunikasi, dan mengembangkan kemampuan baru bagi perencanaan

${ }^{16}$ Utami Munandar, Psikologi Perkembangan Pribadi (Jakarta: UI Press, 2001), 86.

${ }^{17}$ Ibid., 86-87.

${ }^{18}$ Slamet Suyanto, Dasar-dasar Pendidikan Anak Usia Dini (Yogyakarta : Hikayat, 2005), 106. 
dan pengamatan. Vygotsky menyebutkan beragam beragam peralatan psikologi yang digunakan manusia untuk membantu ini sebagai ramburambu berfikir dan bertingkah laku, dan dia berpendapat bahwa kita tidak bisa memahami pikiran manusia tanpa menguji terlebih dahulu tandatanda yang disediakan budaya.

\section{Sosiokulturalisme dalam Pandangan Vygotsky}

Teori Vigotsky merupakan salah satu teori penting dalam psikologi perkembangan teori Vigotsky menekankan pada hakekat sosiokultural dari pembelajaran. Menurut Vygotsky, bahwa pembelajaran terjadi apabila anak bekerja atau belajar mengenai tugas-tugas yang belum dipelajari namun tugas-tugas itu masih berada dalam jangkauan. Kemampuan atau tugas-tugas tersebut berada dalam zona of proximal developmepment. Zona of proximal development adalah perkembangan sedikit di atas perkembangan seorang saat ini. Vygotsky, yakin bahwa fungsi mental yang lebih lebih tinggi pada umumnya muncul pada percakapan atau kerjasama antara individu, sebelum fungsi mental yang lebih tinggi itu terserap kedalam individu tertsebut. ${ }^{19}$

Dalam proses belajar terjadi perkembangan dari pengertian yang spontan dan yang ilmiah. Pengertian spontan adalah pengertian yang didapatkan dari pengalaman anak sehari-hari. Pengertian ini aini adalah tidak terdefinisikan dan tidak terangkai secara sistematis logis. Pengertian ilmiyah adalah pengertian yang didapat dari kelas (sekolah). Pengertian ini adalah pengertian formal yang terdefinisikan secara logis dalam suatu system yang lebih luas. Dalam proses belajar terjadi perkembangan dari pengertian yang spontan ke yang lebih ilmiyah. Vygotsky menggunakan istilah "Zo-Ped" yaitu suatu wilayah tempat bertemu antara pengertian

19 Vygotsky juga meneliti pembentukan dan pengetahuan anak secara psikologis. Namun Vygotsky lebih memfokuskan perhatian kepada hubungan di alektif antara individu dan masyarakat. Dalam pembentukan pengetahuan tersebut. Dia memperhatikan akibat interaksi sosial, terlebih bahasa dan budaya pada proses belajar anak. Menurut Vygotsky, belajar merupakan suatu perkembangan pengertian. Dia membedakan adanya dua pengertian, yang spontan dan yang ilmiah. Pengertian spontan adalah pengertian yang didapatklan oleh dan dari pengalaman anak sehari-hari. Pengertian ini adalah tidak terdefinisikan dan tidak terangakai secara sistematis logis. Pengertian ilmiah adalah pengertian yang didapat dari kelas (sekolah). Pengertian ini adalah pengertian formal yang terdefinisikan secara logis dalam suatu system yang lebih luas. Baca, Yayu Tresna Suci, "Menelaah Teori Vygotsky dan Interdepedensi Sosial sebagai Landasan Teori dalam Pelaksanaan Pembelajaran Kooperatif di Sekolah Dasar", Naturalistic: Jurnal Kajian Penelitan Pendidikan dan Pembelajaran, Vol.3, No.1 (Oktober 2018): 231-239. 
spontan anak dan pengertian sistematis logis orang dewasa. Wilayah ini berbeda dari setiap anak dan ini menunjukkan kemampuan anak dalam menangkap logika dari pengertian ilmiyah. ${ }^{20}$

Dengan diilhami oleh karya Vygotsky, sosiokulturalisme lebih menekankan praktek-praktek kultur dan sosial dalam lingkunagn pelajar. Menurut para sosiokulturalis, aktivitas mengerti selalu di pengaruhi oleh partisipasi seseorang dalam praktek-praktek sosial dan kultur yang ada: situasi sekolah, masyarakat, teman daln lainnya. Bagi Minic, sosiokulturalisme meneliti seorang dalam kegiatan sosialnya. Mereka menerapkan partisipasi seseorang dalam praktek dan kegiatan sosialnya. Mereka menerapkan partisipasi individu dalam praktek dan kegiatn yang diorganisasikan secara cultural, misalnya dalam interaksi dikelas. Pengetahuan yang telah ada sebagai hasil proses dari elemen dasar akan lebih berkembang ketika mereka berinteraksi dengan lingkungan social budaya mereka. Oleh karena itu, Vygotsky sangat menekankan pentingnya peran interaksi sosial bagi perkembangan belajar seseorang. Menurut Vygotsky, pentngnya interaksi social dalam perkembangan kognitif telah melahirkan konsep perkembangan kognitif. Perkembangan kognitif ini berkaitan dengan perkembangan bahasanya. Karena bahasa merupakan kekuatan bagi perkembangan mental manusia. ${ }^{21}$

Hal ini lebih ditegaskan lagi oleh Noeng Muhajir dalam bukunya "Ilmu pendidikan dan perubahan sosial", bahwa Vygotsky mengemukakan ada hubungan antara berfikir dan berbahasa. Vigotsky mengetengahkan tentang adanya dua fase kognisi, yaitu berfikir sinkretik dan fase berfikir kompleksif. Fase pertama juga dia sebutkan sebagai fase praligiustik atau pralogik, yang sifatnya konkrit dan labil. Menurut Vygotsky, bahasa dan berfikir itu mulanya independent satu dengan yang lainnya. Dalam bentuknya paling awal bahasa berfungsi untuk mengekspresikan perasaan dan fungsi social lain: wujudnya menangis, berteriak, mengeluh, bersorak, dan semacamnya. Bentuk-bentuk tersebut disebut oleh Vygotsky sebagai thoughtless language. Sedang berfikir, berfungsi untuk memecahkan masalah. Pada fase kedua inilah bahasa bukan hanya hanya sekedar mengekspresikan perasaan dan fungsi social lainnya, melainkan juga digunakan untuk representasi system abstrak kehidupan manusia. ${ }^{22}$

${ }^{20}$ Ibid.

${ }^{21}$ Baharuddin dan Esatur Waryuni, Teori Belajar dan Pembelajaran (Yogyakarta: Arruz Media, 2007), 125.

22 Noeng Muhajir, Ilmu Pendidikan dan Perubahan Sosial (Yogyakarta: Reka Sarasin, 2003), 54. 
Di sisi lain, berbagai pendapat ahli tentang definisi bahasa, tergantung pada filsafat kebahasaan, seperti yang diungkapkan oleh kaum interaksionisme sosialis, berpendapat bahwa bahasa adalah tidak saja di pandang dari konten proposisi, hubungan logis antara proposisi, tetapi juga melibatkan interprestasi sebagai hasil komunikasi antara pembicara dan pendengar. Interprestasi dapat dilakukan apabila konteks dipahami baik oleh pembicara maupun pendengar. Dengan demikian, dari berbagai uraian di atas dapat kita ketahui bahwa dalam proses pembelajaran Vygotsky menekankan pentingnya interaksi sosial dengan orang lain terlebih yang mempunyai pengetahuan yang lebih baik, dengan sistem yang secara kultural telah berkembang lebih baik. Inilah yang biasa dikenal dengan teori sosiokultural. Dalam teori ini ia menekankan dialog dan komunikasi verbal dengan orang dewasa dalam perkembangan pengertian anak. Dan bahasa merupakan alat yng digunakan untuk berinteraksi memberikan peranan yang amat penting dalam perkembangan kognitif, di samping pengaruh kebudayaan sosial dalam perkembangan kognisi para pelajar.

\section{Dimensi Sosiokultural dalam Pendidikan Islam}

Pendidikan mempunyai peran yang sangat penting dalam keseluruhan aspek kehidupan manusia, karena pendidikan berpengaruh langsung terhadap perkembangan seluruh aspek kepribadian manusia. Dengan kata lain, pendidkan merupakan sebuah proses memanusiakan manusia. Artinya, melalui pendidikan diharapkan manusia mamapu mengembangkan potensinya secara optimal melalui kemampuan bahasa dan berfikir. Pada pengertian lain "pendidikan" diartikan sebagai usaha sadar mengarahkan perkembangan manusia yang bertujuan untuk mendewasakan manusia, agar mereka mampu menolong dirinya sendiri. ${ }^{23}$

Konsep manusia dalam al-Qur'an telah menjelaskan fungsi kekhalifahan manusia sebagai makhluk budaya dan sosial. Pada dasarnya, tugas kekhalifahan manusia adalah tugas kebudayaan yang memiliki ciri kreatifitas agar selalu dapat menciptakan suatu yang baru sesuai dengan kebutuhan pertumbuhan dan perkembangan masyarakat. Tugas kebudayaan manusia menurut al-Qur'an adalah bagaimana menciptakan kemakmuran dan kesejahteraan hidup di muka bumi didasarkan atas kapasitas intelektual dan tuntunan moralnya. ${ }^{24}$

23 Tedi Priatna, Paradigma Pendidikan Islam (Bandung: Pustaka Bani Qurays, 2004), 101.

24 Mo'tasim, "Dimensi Sosiokultural Pendidikan Agama Islam; Analisis Konsep", Al Ibrah; Jurnal Pendidikan dan Keilmuan Islam, Vol. 2, No. 1 (Juni 2017). 
Dalam rangka menciptakan format kebudayaan Islam dan masyarakat Islam nampaknya kita tidak dapat menafikan urgensitas pendidikan Islam sebagai media yang tepat untuk menunnjang dan membantu tugas-tugas terebut. Sebab, bagaimanapun pada dasarnya setiap system pendidkan itu terdiri atas seperangkat cita-cita kemasyarakatan, norma-norma dan nilai-nilai tertentu serta didasarkan atas pandangan hidup dan kebudayaaan tertentu, sehingga kebudayaan dan pendidikan berada dalam suatu bagian yang tidak dapat dipisahkan, keduanya saling membutuhkan dan saling menetukan. Sesuai dengan perkembangan masyarakat yang semakin dinamis sebagai akibat dari kemajuan ilmu pengetahuan dan teknologi, terutama teknologi informasi, maka aktualisasi nilai-nilai Qur'ani menjadi sangat penting. Karena tanpa aktualisasi kitab suci ini, umat Islam akan menghadapi kendala dalam upaya internalisasi nilai-nilai Qur'ani sebagai upaya pembentukan pribadi umat yang beriman, bertakwa berakhlak mulia, cerdas, maju, dan mandiri.

Secara normatif tujuan yang ingin dicapai dalam proses aktualisasi nilai-nilai Qur'ani dalam pendidikan meliputi tiga dimensi yang harus di bina dan harus di kembangkan oleh pendidikan. Pertama, dimensi spiritual yaitu iman, takwa dan akhlak mulia (yang tercermin dalam ibadah dan muamalah). Dimensi spiritual ini tersimpul dalam satu kata yaitu akhlak. Akhlak merupakan alat kontrol psikis dan sosial bagi individu dan masyarakat. Kedua, dimensi budaya yaitu kepribadian yang mantab dan mandiri, tanggung jawab kemasyarakatan dan kebangsaan. Dimensi ini menitik beratkan kepada pembentukan pribadi Muslim sebagai individu yang diarahkan kepada peningkatan dan pengembangan faktor dasar (bawaan) dan faktor ajar (lingkungan), dengan berpedoman kepada nila-nilai keislaman. Dimensi kedua inilah yang dimaksudkan penulis dalam penelitian pustaka ini. Ketiga, dimensi kecerdasan, yang membawa kepada kemajuan yaitu cerdas, kreatif terampil, disiplin etos kerja, professional, inovatif dan produktif. Dimensi kecerdasan dalam pandangan psikologi merupakan sebuah proses yang mencakup tiga proses yaitu, analisis dan kreatifitas dan praktis. ${ }^{25}$

Spidler, mengakui pendidikan itu sebagai transmisi kebudayaan. Ia mengungkapkan bahwa pendidikan sebagai bagian dari proses sosialisasi yang dialami manusia di mana orang muda dipersiapkan untuk menyesuaikan diri dengan baik ke dalam lingkungan intelektual komunitas di mana mereka hidup menjadi dewasa dan menjadi bagian

${ }^{25}$ Said Agil Husin al Munawar, Aktualisasi Nilai-nilai Qur'ani (Ciputat: Mikraj, 2005), 190. 
dari lingkup eksternal di mana hidup komunitas yang lebih luas dan total. Pandangan tentang pendidikan sebagai proses transmisi kebudayaan dan pembentukan kepribadian manusia menurut Goodnough, bahwasanya kebudayaaan itu dapat membentuk pola pikir seseorang. Ia juga mengungkapkan bahwa kebudayaan adalah berbagai standard seseorang untuk mempersepsi, mengevaluasi, meyakini dan melakukan untuk mewujudkan hubungan dengan orang lain sebagai hasil pengalamannya dengan tindakan dan harapan orang lain tersebut. Peranan pendidikan dalam kebudayaan sangat penting. Tugas lembaga pendidikan bukannya mengajar untuk menjadi orang pintar dan pandai tetapi mendidik berarti menuntun tumbuhnya budi pekerti dalam kehidupan agar kelak menjadi manusia yang berpribadi, yang berdab dan bersusila.

Di dalam rumusan-rumusan mengenai kebudayaan terdapat tiga dimensi: manusia, masyarakat dan budaya. Oleh sebab itu, pendidikan tidak dapat terlepas dari kebudayaan karena kebudayaan mempunyai tiga unsure penting yaitu; kebudayaan sebagai suatu tata kehidupan (order), kebudayaan sebagai suatu proses, dan kebudayaan yang mempu nyai suatu visi tertentu (goals), dan pendidikan dalam rumusan tersebut sebenarnya adalah proses pembudayaan. ${ }^{26}$ Di sisi lain, Hery Noer Ali dan Munzer mengungkapkan bahwa manusia berkembang dalam dua dimensinya sekaligus, yaitu individual dan sosial. Lingkungan yang edukatif (lingkungan sosial yang fleksibel) memberi peluang bagi terbentuknya kerangka kultural individual di samping kultural sosial umum. Peluang dan elastisitas yang diberikan lingkungan kepada individu untuk berkembang dan bergerak akan berpegaruh terhadap perkembangan individu and kelompok sekaligus. ${ }^{27}$

Selain itu, pendidikan Islam berusaha pula mengembangkan aspek kemasyarakatan berupa kasih mengasihi, hormat menghormati, sesama Muslim. Perasaan seperti itu apabila sudah tertanam dalam jiwa seseorang dapat menimbulkan tindakan positif berupa tolong menolong dan menjauhkan segala sesuatu yang dapat merugikan orang lain. Allah menjelaskan "Sesungguhnya orang Mukmin itu bersaudara" (Q.S: 49:

${ }^{26}$ Ibid., 192.

27 Pendidikan merupakan proses humanisasi yang dipengaruhi situasi dan kondisi, serta berfungsi sebagai bingkai kultur dengan konstruksinya yang kompleks. Oleh sebab itu, persoalan pendidikan hendaknya ditinjau dalam perspektif berfungsinya berbagai hubungan, pola dan masalah alam pembentukan individu-individu serta berbgai fenomena-fenomena sosial yang mereka alami. Sebab semuanya merupakan produk berbagai kondisi, faktor, hubungan sosial, dan pengaruh kultural. Lihat Hery Noer Ali dan Munzir, Watak Pendidikan Islam (Jakarta: Friska Agung Insani, 2003), 178. 
10). Begitu pula Rasulullah SAW bersabda: "tidaklah sempurna iman seseorang di antaramu sebelum Ia mencintai saudaranya sebagai mana Ia mencintai dirinya sendiri (HR. Bukhori). ${ }^{28}$ Implikasinya dalam pendidikan adalah bahwa dalam pembentukan kepribadian yang harmonis sebagai tujuan akhir pendidikan Islam prinsip keseimbangan harus diperhatikan, karena kepribadian akan harmonis kalau segala aspekaspeknya bekerja secara seimbang. Dalam segi tertentu, pendidikan merupakan usaha manusia untuk memanusiakan anak manusia. Setiap usaha dan karya manusia hasilnya bisa disebut dengan istilah kebudayaan. Jelasnya kebudayaan adalah hasil budidaya manusia dengan memanfaatkan potensi, cipta, rasa, dan karsanya. Atas dasar pandangan ini, sesungguhnya pendidkan itu termasuk kebudayaan karena pendidikan memiliki kaitan dengan kebudyaan dan masyarakat. ${ }^{29}$

Oleh karena pendidikan sebagai suatu gejala kehidupan tidak dapat dilepaskan dari seluruh gejala kehidupan sosial lainnya, termasuk kebudayaan. Hubungan timbal balik dan saling bergantung antara keduanya merupakamn kenyataan yang tidak bisa kita pungkiri. Yang terpenting adalah bagaimana memfungsikan pendidikan Islam sebagai formulasi untuk memelihara, mentransformasikan dan mengembangkan serta merekayasa kebudayaan serta kemasyarakatan yang bernilai Islam. Selain itu, pendidikan Islam yang didasari konsep manusia menurut alQr'an harus mencerminkan visi obyektif mengenai realitas kekinian dan visi definitif tentang realitas ideal masa depan tentu nya untuk mengeiternalisasikan semua nilai itu dalam substansi pendidikan Islam, diperlukan upaya lebih nyata dalam mendeskripsikan tujuan pendidikan Islam sebagai alat yang digunakan manusia untuk kelanjutan hidupnya baik dalam artian sebagai upaya masyarakat untuk mewarisi nilai-nilai budaya dari generasi ke generasi, ataupun dalam mengembangkan potensi- potensi yang ada pada individu, agar dapat di pergunakan oleh dirinya dan seterusnya oleh masyarkat untuk menghadapi kendalakendala lingkungan sekitarnya.

\section{Pendekatan Sosiokulturalisme dalam Pendidikan Islam}

Sebagaimana telah diuraikan di atas, maka untuk mengaplikasikan pendekatan-pendekatan sosiokultural dalam pendidkan Islam yakni dengan mengetahui terdahulu bagaimana metodologi pendidikan Islam.

${ }^{28}$ Ramayulis, Ilmu Pendidikan Islam (Jakarta : Kalam Mulia, 1998), 116.

${ }^{29}$ Lihat Miftahur Rohman dan Hairudin Hairudin, "Konsep Tujuan Pendidikan Islam Perspektif Nilai-nilai Sosial-kultural”, Al-Tadzkiyyah: Jurnal Pendidikan Islam, Vol. 9, No. 1 (2018). 
Kemudian dengan metode-metode tersebut dapat disesuaiakan dengan kondisi dan situasi yang sesuai dengan konsep sosiokultural dalam proses sistem pendidikan Islam. Setelah mengetahui berbagai konsep kependidikan Islam sebagaimana telah diuraikan di awal pembahasan, dalam pendidikan Islam telah di letakkan dasar-dasar Al-Qur'an berkenaan dengan tujuan pendidikan dan meteri yang harus diajarkan dalam pendidikan Islam. Kedua hal tersebut lebih bersifat teoritikal, sedangkan metodologi pendidikan persoalan yang praktis dan mempunyai kedudukan yang sangat penting dalam upaya mencapai pendidikan Islam. Oleh karena dengan metode, pendidikan Islam itu akan tercapai secara tepat guna manakala jalan yang ditempuh menuju cita-cita tersebut betulbetul tepat.

Metodologi pendidikan adalah suatu ilmu pengetahuan yang digunakan dalam pekerjaan mendidik. Asal kata "Metode" mengandung pengertian "suatu jalan yang dilalui untuk mencapai suatu tujuan". Metode berasal dari dua perkataan yaitu "meta" dan "hodos". Meta berarti "melalui" dan hodos berarti "jalan atau cara", bila ditambah dengan logi yang berasal dari bahasa greek (yunani) logos berarti akal dan ilmu. "Metodologi" berarti "ilmu pengetahuan tentang jalan atau cara yang harus dilalui" untuk mencapai suatu tujuan. ${ }^{30}$ Sebagai salah satu disiplin ilmu metodologi pendidikan Islam mempunyai tugas dan fungsi memberikan jalan atau cara yang sebaik mungkin dalam pelaksanaan operasional dari ilmu pendidikan Islam tersebut. Pelaksanaannya berada dalam ruang lingkup proses kependidikan yang berada di dalam suatu sistem dan struktur kelembagaan yang diciptakan untuk mencapai pendidikan Islam. Menurut M. Arifin dalam penerapannya, metodologi pendidikan Islam menyangkut wawasan keilmuan kependidikan yang bersumber pada al-Qur'an dan al-Hadith. ${ }^{31}$

${ }^{30}$ Arifin, Ilmu Pendidikan Islam, 65.

${ }^{31}$ Untuk mendalaminya kita perlu mengungkapkan implikasi-implikasi metodologi kependidikan dalam kitab suci al-Qur'an dan Al-Hadith antara lain sebagai berikut: Pertama, gaya bahasa dan ungkapan yang terdapat dalam Al-Quran menunjukakan fenomena bahwa firman-firman Allah itu mengandung nilai-nilai metodologis yang mempunyai corak dan ragam sesuai tempat dan waktu serta sasaran yang dapat dihadapi. Firman-firmanNya itu senantiasa mengandung hikmah kebijaksnaan yang secara metodelogis disesuaikan kecendrungankecendrungan atau kemampuan kejiwaan manusia yang hidup dalam situasi dan kondisi tertentu yang berbeda-beda. Jadi metode yang dipergunakan oleh Allah adalah metode pemberian alternatif-alternatif (pilihan) menurut akal pikiran, yang berbeda kemamapuannya antara yang satu dengan yang lain. Kedua, dalam memberikan perintah dan larangan (imperatif-preventif) Allah senantiasa memperhatikan kadar kemampuan masing-masing hambanya, segala taklif (beban) 
Di samping itu dalam menentukan kandungan pendidikan Islam, Atiyah al-Abrasyi menandaskan adanya enam prinsip. Pertama, pengaruh kandungan itu dalam pendidikan jiwa. Dalam hal ini harus diutamakan materi yang memperkenalkan sekaigus mempertebal kepercayaan kepada Tuhan. Kedua, pengaruh kandungan pendidikan Islam dalam bidang petunjuk, tuntunan, dengan menjalani cara hidup, yang mulia, sempurna seperti dengan ilmuakhlak, Hadi>th, dan fiqih serta yang lainnya. Ketiga, Pengaruh kandungan pendidikan dalam menjaga kelangsungan hidup baik yang bersifat fisik maupun intelek. Keempat, pengaruh kandungan pendidikan dalam memuaskan pembawaan fitrah bahwa manusia cinta ilmu pengetahuan. Kelima, kandungan pendidikan yang bersifat teknik. Pendidikan Islam tidak mengesampingkan materi (ilmu) yang bersifat kejuruan dalam beberapa bidang pekerjaan. Dan yang keenam, mempelajari materi adalah alat pembuka jalan untuk mempelajari ilmuilmu yang lain.

Memperhatikan keenam prinsip di atas dapat disimpulkan bahwa pendidkan Islam mengutamakan pembinaan semangat dan sikap keagamaan yang didukung dengan pengetahuan, tingkah laku dan kejiwaan nafsani yang baik. Di samping itu pendidikan Islam juga memperhatikan subyek-subyek kebudayaan, kejuruan serta latihanlatihan praktis dan pemikiran dalam menghadapi kebutuhan hidup. Dalam hal ini rasul bersabda "bekerjalah untuk duniamu seakan-akan kamu akan hidup selamanya. Dan bekerjalah untuk akhiratmu seakan- akan kamu akan meninggal besok pagi". ${ }^{32}$

Berdasarkan sistem pendekatan dari berbagai disiplin keilmuan di atas, suatu metode pendidikan baru dapat diterapkan secara efektif, manakala perkembangan anak didik dipandang dari berbagai aspek perkembangan kehidupannya. Apabila dikaitkanm dengan metodologi pendidikan Islam kemungkinan-kemungkinan tersebut harus senantiasa diusahakan untuk diungkapkan melalui berbagai metode yang di dasarkan

Nya berbeda-beda meskipun diberikan tugas yang sama. Dengan demikian perbedaan-perbedaan individual anak didik, bila dilihat dari segi metodologis kandungan Al-Qur'an, diakui dan dihormati sehingga heterogenisis manusia tetap eksis (ada) di dalam dunia ini. Ketiga, sistem pendekatan metodelogis yang diterangkan di dalam Al-Qur'an bersifat multi approach yang meliputi antara lain sebagaimana disebutkan pada bab sebelumnya. Lihat, Arifin, Ilmu Pendidikan Islam, 67. Bandingkan dengan Mo'tasim, "Dimensi Sosiokultural Pendidikan Agama Islam; Analisis Konsep", Al Ibrah; Jurnal Pendidikan dan Keilmuan Islam, Vol. 2, No. 1 (Juni 2017).

32 Jamali Syahrodi, Membedah Nalar Pendidikan Islam (Yogyakarta: Pustaka Rihlah, 2005), 63. 
atas pendekatan yang multidimensional sehingga yang dicontohkan dalam uslub dan manhaj (langkah pedagogis) dari firman-firman Allah dalam al-Qur'an. Penggunaan metode didasarkan atas tiga aspek pokok, yaitu: 1) Sifat-sifat dan kepentingan yang berkenaan dengan tujuan utama pendidikan Islam, yaitu pembinaan manusia mukmmin yang mengaku sebagai hamba Allah; 2) Berkenaan dengan metode yang betul-betul berlaku yang disebutkan dalam Al-Qur'an atau disimpulkan dari padanya; 3) Berbicara tentang pergerakan (motivation) dan disiplin dalam istilah al-Qur'an yang disebut ganjaran (sawab) dan hukuman (iqlab). ${ }^{33}$

Ahmad Tafsir, mengemukakan bahwa, metode itu harus dimasukkan sebagai salah satu aspek saja dalam suatu sistem mengajar. Yang dapat membantu seseorang untuk dapat mengajar bukanlah penguasaan terhadap metode, melainkan petunjuk tentang bagaimana merancang "jalan mengajar" yaitu urutan langkah mengajar, antara lain: 1) Langkah mengajar ditentukan oleh tujuan pengajaran yang hendak dicapai; 2) Langkah mengajar ditentukan oleh kemampuan guru yaitu disesuiakan denganrumusan tujuan pengajaran; 3) Langkah mengajar ditentukan oleh keadaan alat-alat yang tersedia; 4) Langkah menga jar ditentukan oleh banyaknya murid. ${ }^{34}$

Selanjutnya dalam dalam pembelajaran dan pendidikan bisa digunakan berbagai metode sesuai dengan situasi dan kondisi. Pertama, metode dialog (al-hiwār). Metode dialog adalah suatu metode pendidikan yang dilakukan denngan percakapan atau Tanya jawab antara dua orang atau lebih secara komunikatif mengenai suatu topek. Metode ini memberikan kesem patan kepada anak didik untuk berpikir kritis dan objektif dalam masalah-masalah yang diajarkan sehingga diperoleh formula pengetahuan yang signifikan bagi diri dan sosial. Kedua, metode cerita (al-qishaș). Metode cerita dimaksudkan untuk memberi pengetahuan dan perasaan kepada anak didik. Al-Qur'an dan Hadith lebih banyak meredaksikan kisah-kisah untuk menyampaikan pesanpesannya. Anak didik diberikan kebebasan untuk menafsirkan dan menginterpretasikan nilai-nilai yang dikandung di dalam kisah tersebut. Anak didik diharapkan memiliki kepekaan intelektual (Intelektual ability) sekaligus kepekaan emosional (emosional majurity) dalam pembelajaran kisah untuk "dianggit" dalam "anyaman" kehidupan diri dan sosialnya.

Ketiga, metode perumpamaan (al-amtsal). Metode perumpamaan adalah suatu metode yang digunakan untuk mengungkapkan suatu sifat dan hakikat dari realitas sesuatu. Seperti Allah SWT yang mengumpamakan berhala sebagai sesembahan dan penolong oleh kaum

\footnotetext{
${ }^{33}$ Ramayulis, Ilmu Pendidikan Islam (Jakarta : Kalam Mulia, 1998), 78.

34 Tafsir, Ilmu Pendidikan Perspektif Islam, 132.
} 
musyrik laksana sarang laba-laba yang rapuh, (QS. Al-Ankabut : 4 ) dan (QS. Al-Jumu'ah : 5). Metode ini banyak dipergunakan dalam pendidikan Qur'ani dan sunnah Nabawi. Tujuan pokok metode ini adalah mendekatkan makna (hal yang abstrak) pada pemahaman merangsang pesan dan kesan untuk menumbuhkan berbagai perasaan ketuhanan, mendidik akal berpikir logis, dan menghidupkan serta mendorong naluri atau penghayatan hati secara mendalam.

Keempat, metode keteladanan (uswah). Keteladanan pendidikan merupaikan syarat mutlak yang harus melekat pada pendidik/Guru. Seringkali anak didik itu melakukan sesuatu tindakan bukan berdasar suatu latihan (trial and error), tetapi ia melakukan sesuatu yang orang lain melakukannya. Pada fase demikian anak didik sedang dalam proses identifikasi kepribadian yang cendrung meniru orang lain. Dalam konteks pendidikan dan pembelajaran metode ini menuntut personifikasi kepribadian pendidik/Guru. Begitu urgennya metode ini sehangga alQur'an mengabadikan dan melukiskan pribadi Nabi SAW dalam relasi dengan sahabat-sahabatnya. ${ }^{35}$

Kelima metode sugseti dan hukuman (at-tarwib wa at-tarhi). Sugesti adalah janji yang disertai bujukan dan dorongan rasa senang kepada sesuatu yang baik. Anak didik dimotivasi kearah sesuatu yang baik melalui janji-janji.yang memungkinkan mereka untuk aktualisasi.kedua metode dimaksudkan untuk membentuk kepribadian anak didik yang baik. Keenam metode nasihat/penyuluhan (almaw'izhah). Pemberian nasihat/penyuluhan kepada anak didik adalah suatu yang niscaya untuk menumbuhkan kesadaran dan menggugah perasaan serta kemauan untuk mengamalkan apa yang diajarkan/dipelajari. Metode ini dimaksudkan untuk memotivasi anak didik untuk melakukan yang makruf dan menjauhi yang mungkar. Penyuluhan bisa diartikan sebagai proses bimbingan kepada anak didk ebagai subjek individu dan sosial yang perlu diaktualisasikan potensi dan kompetensinya secara maksimal.

Ketujuh metode meyakinkan dan memuaskan (al-iqna' wa aiqtina'. Adalah metode yang dimainkan dengan cara membangkitkan kesadaran anak didik dalam melakukan suatu perbuatan. Islam adalah agama yang sesuai dengan akal pikiran dan jiwa manusia, bukan ajaran yang bersifat dogmatis. Proses pembelajaran dan pendidikan yang meyakinkan akan mengantarkan anak didik kearah kesadaran motivasional untuk melangsungkan kegiatan pembelajaran/belajar sepanjang masa. Jadi penampilan (performance) seorang guru dalam

${ }^{35}$ Ibid., 132-133. 
proses pembelajaran dan pendidikan merupakan prasyarat betah tidaknya anak didik di dalam dan untuk belajar.

Kedelapan, metode pemahaman dan penalaran (al-ma'ifah wa alnazhariyyah). Metode ini digunakan dengan membangkitkan akal dan kemapuan berpikir anak didik secara logis. Dalam metode mayakinkan dan penalaran ini sasaran utamanya pada pembinaan kemampuan berpikir logis dan kritis. Kesembilan metode latihan perbuatan (al-mumaritsah wal amaliyyah). Adalah melatih atau membiasakan anak didik melakuakn sesuatu yang baik. Melalui metode ini anak diharapkan mengetahui dan sekaligus mengamalkan materi pelajaran yang diajarkan.yang mendasari metode ini adalah ajaran Islam yang menghendaki satu kesatuan antara ilmu dan amal, atau antara kata dan perbuatan. Anak bisa mengaktualisasikan apa yang di pelajari disekolah kedalam dunia realitasnya. ${ }^{36}$

Di samping itu, kesempurnaan tujuan yang disesuaikan dengan metode-metode mulai dari metode verbalisme verbal sampai interaksi langsung dari situasi belajar mengajar, sebagai contoh, mengadakan perjalanan untuk menuntut ilmu atau belajar. Pendidikan Islam yang terkait dengan pembentukan-pembentukan pribadi daalm kependidikan, menjadikan sasaran pada metoda-metoda bertumpu kepada tujuan pendidikan. Sehingga tercapai kepada tingkat yang sempurna. Dalam hal ini kurikulum tidak boleh dikacaukan dengan definisi pengajaran sekuler dan nonreligius. ${ }^{37}$

Dengan demikian, apapun metode yang digunakan dalam proses pembelajaran dan pendidikan Islam yang perlu di perhatikan adalah akomodasi menyeluruh terhadap prnsip-prinsip kegiatan belajar mengajar. Yang terpenting adalah supaya proses belajar dan pembelajaran menyenangkan baik pendidik ataupun peserta didik supaya lebih kreatif dan rekreatif dalam menjalankan aktivitas pendidikan. Yakni dengan pendekatan-pendekatan sosial dalam pelaksaan pembelajan dengan tidak menafikan aturan-aturan Islam dalam proses pembelajaran sebagaimana yang telah tercantum dalam landasan ajaran Islam, yaitu alQur'an dan Hadith.

${ }^{36}$ Imam Tholkhah dan Ahmad Barizi, Membuka Jendela Pendidikan (Jakarta: Raja Garfindo Persada, 2004), 216.

37 Abdurrahman Shaleh Abdullah, Teori-teori Berdasarkan al-Qur'an (Jakarta: Rineka Cipta, 2005), 237. 


\section{Sosiokulturalisme dalam Dua Cermin; Sintesis Pemikiran}

Setelah penulis meneliti dan memahami pembahasan pada bab-bab sebelumnya, penulis dapat menyatakan bahwa pemikiran Vygotsky tentang hakikat sosiokultural sangatlah penting dalam proses pembelajaran. Menurutnya bahwa pembelajaran terjadi bila anak bekerja atau belajar mengenai tugas-tugas yang belum dipelajari namun tugastugas tersebut masih berada dalam jangkauannya, yang dalam istilahnya Vygotsky menyebutnya dengan konsep Zona proksimal Development. Vygotsky yakin bahwa fungsi mental lebih tinggi pada umunya muncul daalm percakapan atau kerjasama antara individu, sebelum fungsi mental yang lebih tinggi itu terserap kedalam individu. Dengan kata lain, pembentukan pengetahuan seseorang merupakan akibat dari interaksi sosial, terlebih bahasa dan budaya pada proses pembelajaran.

Menurut Vygotsky belajar merupakan suatu pengembangan pengertian dari pengertian spontan dan pengertian ilmiyah. Pengertian spontan ini menurutnya adalah pengertian yang didapatkan dari pengalaman sehari-hari, tidak terdefinisikan dan tidak pula terangkai secara sistematis logis. Adapun pe ngertian ilmiyah adalah pengertian yang didapat dari sekolah atau pengertian formal yang terdefinisikan secara logis dan sistematis. ${ }^{38}$ Di samping itu Vygotsky juga berpendapat bahwa, kerja mental juga akan lebih mudah bila ada alat pendukungnya yang ia sebut dengan Tool of the mind yang berfungsi untuk memudahkan anak unutk memahami suatu fenomina, memecahkan masalah, mengingat dan berfikir. ${ }^{39}$ Sebagai contoh batu, manik-manik atau lidi, merupakan alat yang dapat membantu anak memahmi konsep bilangan. Anak dapat menghubungkan benda tersebut dengan bahas symbol seperti "satu, dua, tiga" dan seterusnya. Pada masa ini, anak perlu banutan dari orang dewasa atau teman sebaya yang lebih kompeten, yaitu guru atau teman sebayanya.

Bantuan tersebut bisa berupa contoh, petunjuk, peringatan, dorongan, menguraikan masalah dalam bentuk lain yang memungkinkan

\footnotetext{
38 Vygotsky menggunakan istilah zona proximal defelopment yaitu suatu wilayah tempat bertemu antara pengertian spontan dan pengertian ilmiyah. Dan wilayah ini berbeda pada setiap individu yang menunjukkan bahwa kemampuan individu berbeda dalam menangkap logika dari pengertian ilmiyah. Menurutnya aktivitas mengerti dipengaruhi oleh partisipasi seseorang dalam praktek-praktek sosial dan kultural yang ada. Oleh karena itu Vygotky menekankan pada pentingnya interaksi sosial bagi perkembangan belajar seorang siswa. Lihat, Edmore Mutekwe, "Using a Vygotskian Sociocultural Approach to Pedagogy: Insights from Some Teachers in South Africa", Journal of Education, No. 71 (2018).

${ }^{39}$ Ibid.
} 
manusia untuk dapat mandiri, yang oleh Vygotsky dinamakan dengan istilah scaffolding. Jadi, scaffolding berarti memberikan sejumlah besar bantuan selama tahap-tahap awal pembelajaran, kemudian mengurangi bantuan tersebut dengan memberikan kesempatan kepada anak tersebut mengambil alih tanggung jawab yang semakin besar setelah maampu mengerjakan sendiri. Dengan kata lain pendidikan dan pengajaran harus membantu anak didik untuk aktif belejar sendiri. Namun, pengetahuan juga dapat dibentuk dalam kerjasama dengan teman lain (secara sosial). ${ }^{40}$

Sedangkan dalam perspektif pendidikan Islam, pendidikan mempunyai peran sangat penting dalam keseluruhan aspek kehidupan manusia. Karena pendidikan berpengaruh langsung terhadap perkembangan seluruh aspek kepribadian manusia. Artinya melalui pendidikan diharapkan manusia mampu mengembangkan potensinya secara optimal melalui kemampuan bahasa dan berpikir. Di samping itu perbedaan corak pendidikan dalam perspektif Islam salah astunya disebabkan oleh perbedaan pandangan tentang konsepsi manusia. Oleh sebab itu berbicara mengenai pendidikan Islam maka, untuk lebih memahaminya terlebih dahulu harus diungkapkan bagaimana konsepsi manusia menurut Islam.

Konsepsi manusia dalam al-Qur'an telah menegaskan fungsi kekholifahan manusia sebagai makhluk sosial dan budaya. Pada dasarnya tugas kekhalifahan manusia adalah tugas kebudayaan yang memiliki ciri kreatifitas agar selalu dapat menciptakan suatu yang baru, sesuai dengan kebutuhan pertumbuhan dan perkembangan masyarakat. Tugas kebudayaan manusia dalam al-Qur'an adalah bagaimana menciptakan kemakmuran dan kesejahteraan hidup di muka bumi berdasarkan atas kapasitas intelektual dan tuntuan moralnya. Di dalam rumusan-rumusan mengenai kebudayaan terdapat tiga dimensi, yaitu manusia, budaya dan masyarakat. Oleh sebab itu, pendidikan tidak lepas dari kebudayaan karena kebudayaan mempunyai tiga unsur penting yaitu: sebagai suatu tata kehdupan (order), kebudayaan sebagai suatu proses, dan kebudayaan mempunyai suatu visi tertentu. ${ }^{41}$

${ }^{40}$ Vygotsky menekankan pentingnya kerjasama, studi kelompok, dan dalam studi kelompok itu peran seorang guru (pendidik) adalah sebagai fasilitator dan moderator. Tugasnya adalah merangsang dan membantu siswa untuk belajar sendiri dan merumuskan pengertiannya sendiri. Baca, Huy P. Phan, "A Sociocultural Perspective of Learning: Developing a new Theoretical Tenet", Joint AARE APERA International Conference, (Sydney: 2012).

41 Pendidikan sebenarnya adalah proses pembudayaan. Oleh sebab itu, persoalan pendidikan hendaknya ditinjau dalam perspektif berfungsinya berbagai hubungan, El-Banat Vol. 9. No.2 (2019) 255 
Pada prisipnya pendidikan Islam adalah pendidikan yang seimbang. Ada beberapa prinsip yang mendasari keseimbangan pendidikan Islam yaitu keseimbangan antara duniawi dan ukhrawi, keseimbangan antara badan dan roh, dan keseimbangan antara individu dan dan masyarakat. Maka pendidikan Islam berusaha mengembangkan semua aspek dan daya yang ada pada manusia secara seimbang. Manusia lahir kedunia ini dibekali kecendrungan pembawaan daya imajinasi dan akal yang berbeda sebagaimana firmanNya: QS. Al-isra': 21 .

"Perhatikanlah bagaimana Kami lebihkan sebagian dari mereka atas sebagian (yang lain). Dan pasti kehidupan akhirat lebih Tinggi tingkatnya dan lebih besar keutamaannya. ${ }^{42}$

Dari ayat tersebut jelaslah bahwa pendidikan Islam memperhatikan perbedan individu sebagai salah satu factor yang harus di pertimbangkan dalam menyusun program pendidikan. Oleh sebab itu pendidikan Islam bertanggung jawab dalam pengembangan setiap individu anak sesuai dengan tabiatnya. Di samping itu, sebagai aktifitas yang bergerak daalm pendidkan dan pembinaan kepribadian, pendidikan Isalm memerlukan lanndasan kerja guna memberikan arah bagi program yang akan dilakukan. Landasan tersebut berasal dari al-Qur'an surat Sy-Syu'ara ayat 52 :

"Dan Kami wahyukan (perintahkan) kepada Musa: "Pergilah di malam hari dengan membawa hamba-hamba-Ku (Bani Israil), karena Sesungguhnya kamu sekalian akan disusuli". ${ }^{43}$

Dari ayat tersebut dapat diambil kesimpulan bahwa al-Qur'an diturunkan kepada umat manusia untuk memberikan petunjuk, kearah jalan hidup yang lurus, dalam arti memberikan bimbingan dan petunjuk kearah jalan yang diridlai Allah. Dalm hal ini tugas pendidikan adalah menegakkan dan membimbing anak agar ia menjadi dewasa. Untuk itu, dalam mengembangkan potensi dan kemampuannya, maka manusia membutuhkan adanya bantuan dari orang lain untuk membimbing, mendorong, mengajari dan mengarahkan agar berbagai potensi tersebut tumbuh dan berkembang secara wajar, optimal dan maksimal. Dengan demikian dalam transformasi pendidikan Islam seharusnya memperhatikan adanya kepekaan terhadap materi, metode dan media pembelajaran serta kompetensi eksistensial anak didik. Yang paling

pola dan masalah dalam pembentukan-pembentukan individu serta berbagai fenomina sosial yang mereka alami.

${ }^{42}$ Depag RI, Al-Qur'an' dan Terjemahnya (Surabaya: Al-Hidayah, 1998), 427.

${ }^{43}$ Ibid., 577. 
penting dalam proses pembelajaran adalah bagaimana mengaktualisasikan segenap potensi dan kompetensi anak didik. Yaitu memberikan layanan pendidikan yang mengarah kepada peran aktif anak dari pendidik. Aktifitas anak didik diperankan secara maksimal dalam proses pendidikan dan pembelajaran. Dan guru tak lebih hanya berperan sebagai fasilitator dan dan supervisor akademik. Guru mengantarkan kompetensi personal anak didik kearah yang dituju.

Berdasarkan pemaparan tentang konsepsi Vygotsky dan pendidikan Islam di atas maka dapat diambil titik persamaan antara keduanya yaitu: dalam proses pendidikan dan pembelajaran, pengetahuan individu terbentuk melalui interaksi sosial dan budaya sangat berpengaruh dalam pembentukan pola pikir dan kemandirian individu tersebut. Dan setiap manusia (anak didik) mempunyai kemapuan (potensi) yang berbeda, untuk itu dalam proses pendidikan dan pembelajaran harus memperhatikan perbedaaan-perbedaan tersebut, supaya anak didik dapat berperan aktif dan maksimal. Di samping itu, individu (anak didik) juga memerlukan bantuan, dorongan dan petunjuk serta bimbingan selama proses pembelajaran untuk membentuk suatu kemandirian. Dalam hal ini guru berfungsi sebaagi fasilitator, yang bertugas dan berperan merangsang, membantu dan mengantarkan anak didik kearah yang di tuju dengan belajar sendiri dan merumuskan pengertiannya sendiri. Dengan demikian, dari persamaan dan perbedaan antara kosepsi teori sosiokultural Vygotsky dengan konsepsi dasar pendidikan Islam dalam proses pembelajaran sebagaimana telah disebutkan di atas, berbeda dengan konsepsi Vygotsky yang lebih menekankan pada pentingnya pengaruh faktor sosial dalam pembelajaran, pendidikan Islam bukanlah sekedar menekaankan pada iteraksi sosial dalam pembelajaran. Akan tetapi lebih luas lagi cakupannya, yakni menekankan pada keseimbangan antara duniawi dan ukhrawi. ${ }^{44}$

Pencarian konsep pendidikan Islam yang ideal seperti tersebut di atas, menurut hemat penulis dapat dilakukan melalui sintesa antara pendidikan Islam tradisional dan barat moderen sepanjang tetap menjadikan Islam sebagai landasan sentral filosofis. Dalam spirit pendidikan Islam yang dicoba disintesakan oleh penulis di dalam artikel

44 Di samping memperhatikan pada interaksi sosial yang berupa latihan-latilan praktis dan pemikiran-pemikiran, pendidikan Islam juga mengutamakan pembinaan semangat dan sikap keagamaan. Dalam hal ini proses pengembangan pendidikan Islam berdsarkan pada prinsip keseimbangan, yaitu beruaha mengembangan semua aspek dan daya yang ada pada manusia. Sehingga pada nantinya akan tercapai tujuan akhir pendidikan, yaitu membentuk manusia seutuhnya (insan al kamil). 
ini mengandung nilai sosial kemasyarakatan dalam proses pembelajaran. Dari sini berarti konsep pembelajaran Vygotsky tidak bertentangan dengan nilai ajaran Islam yang memang menghendaki adanya interaksi sosial dalam proses pembelajaran bahkan lebih dari itu pendidikan Islam sangat memperhatikan semua aspek dan daya yang ada pada manusia.

Dengan demikian, konsep pendidikan Islam yang disintesakan dengan konsep Vygotsky dalam pembelajaran Islam diharapkan akan menjadi konsep pendidikan dan pembelajaran yang ideal, yaitu proses pendidikan dan pembelajaran melalui pendekatan sosiokultural. Sehingga dalam proses ini terjadi interaksi sosial yang harmonis bagi manusia baik sebagai subjek didik ataupun sebagai objeknya. Yang sesuai dengan indikasi kependidikan Islam yang lebih menekankan kepada praktek (pengamalan) sebagai kholifah Allah di muka bumi. Yakni dengan pengabdian diri kepada Allah sepenuhnya demi tercapainya kebahagiaan di dunia dan akhirat.

\section{Kesimpulan}

Pada bagian terakhir ini, penulis menyimpulkan bahwa konsepsi teori sosiokultural dalam proses pembelajaran perspektif Vygotsky adalah menekankan pada dua konsep penting antara lain Zona Of Proximal of Development yaitu suatu wilayah tempat bertemu antara pengertian spontan dan pengertian ilmiyah dan wilayah ini ada pada setiap individu yang menunjukkan bahwa kemampuan individu berbeda dalam menangkap logika dari pengrtian ilmiyah. Menurutnya aktifitas mengerti dipengaruhi oleh partisipasi seseorang dalam praktek-praktek sosial dan kultur yang ada. Pemikiran Vygotsky dan pendidikan Islam tentang proses pendidikan dan pembelajaran mempunyai persamaan pada pembentukan pengetahuan individu yaitu terbentuk melalui interaksi sosial, dan budaya sangat berpengaruh dalam pembentukan pola pikir dan kemandirian individu. Sedangkan perbedaan di antara keduanya adalah menurut Vygotsky menekankan pentingnya peran interaksi sosial (pembelajaran sosiokultural) bagi perkembangan belajar seseorang, dan proses pengembangan tersebut tanpa tujuan akhir kecuali untuk membentuk tingkatan kognitif yang lebih tinggi dan mengalir sejalan dengan perubahan yang ada di lingkungannya. Sedangkan perspektif pendidikan Islam lebih menekankan pada keseimbangan antara duniawi dan ukhrawi, artinya di samping mempertimbangkan subyek-subyek kebudayaan, latihan-latihan praktis dan pemikiran, pendidikan islam megutamakan pembinaan semangat dan sikap keagamaan. Dan proses pengembangan pendidikannya ada tujuan akhir yaitu penghambaan diri kepada Allah. Dalam hal ini pendidikan Islam berdasarkan prinsip 
keseimbangan. Artinya pendidikan Islam berusaha mengembangkan semua aspek dan daya yang ada pada manusia.

\section{Daftar Rujukan}

Abbas, Saleh. Pembelajaran Bahasa Indonesia yang Efektif di Sekolah Dasar. Jakarta: Departemen Pendidikan Nasional, 2006.

Abdullah, Abdurrahman Shaleh. Teori-teori Berdasarkan Al-Qur'an. Jakarta: Rineka Cipta, 2005.

Ali, Hery Noer dan Munzir. Watak Pendidikan Islam. Jakarta: Friska Agung Insani, 2003.

Arifin, M. Ilmu Pendidikan Islam. Jakarta: Bumi Aksara, 1993.

Baharuddin dan Waryuni, Esatur. Teori Belajar dan Pembelajaran. Yogyakarta: Arruz Media, 2007.

Bodrova, Elena \& Leong, Deborah J. "Vygotskian and Post-Vygotskian Views on Children's Play". American Journal of Play, Vol. 7, No. 3 (2015).

Bodrova, Elene. "Key Concepts of Vygotsky's Theory of Learning and Development". Journal of Early Childhood Teacher Education, Vol. 18, No. 2 (1997).

Crain, Willam Teori Perkembangan; Konsep dan Aplikasi. Yogyakarta: Pustaka Pelajar, 2007.

Danoebroto, Sri Wulandari. "Teori Belajar Konstruktivis Piaget dan Vygotsky". Indonesian Digital Journal of Mathematics and Education, Vol. 2 No. 3 (2015).

Depag RI. Al-Qur'an' dan Terjemahnya. Surabaya: Al-Hidayah, 1998.

Esteve, Olga., Fernández, Francesc., Bes, Asunción. "Pre-service Teacher Education from a Sociocultural Perspective: A Case-Study on Teaching Learning through Conceptual Mediation". Journal of Language and Sociocultural Theory, Vol. 5, No. 2 (2018).

Gunarsa, Singgih D. Dari Anak Sampai Usia Lanjut. Jakarta : BPK Gunung Mulia, 2004.

Mo'tasim. "Dimensi Sosiokultural Pendidikan Agama Islam; Analisis Konsep". Al Ibrah; Jurnal Pendidikan dan Keilmuan Islam, Vol. 2, No. 1 (Juni 2017). 
Muhajir, Noeng. Ilmu Pendidikan dan Perubahan Sosial. Yogyakarta: Reka Sarasin, 2003.

Munandar, Utami. Psikologi Perkembangan Pribadi. Jakarta: UI Press, 2001.

Munawar (al), Said Agil Husin. Aktualisasi Nilai-nilai Qur'ani. Ciputat: Mikraj, 2005.

Mutekwe, Edmore. "Using a Vygotskian Sociocultural Approach to Pedagogy: Insights from Some Teachers in South Africa". Journal of Education, No. 71 (2018).

Ningsih, Asri Budi. Belajar dan Pembelajaran. Jakarta: Rineka Cipta, 2005.

Phan, Huy P. "A Sociocultural Perspective of Learning: Developing a new Theoretical Tenet", Joint AARE APERA International Conference. Sydney: 2012.

Priatna, Tedi. Paradigma Pendidikan Islam. Bandung: Pustaka Bani Qurays, 2004.

Ramayulis. Ilmu Pendidikan Islam. Jakarta : Kalam Mulia, 1998.

Rohman, Miftahur dan Hairudin. "Konsep Tujuan Pendidikan Islam Perspektif Nilai-nilai Sosial-kultural". Al-Tadzkiyyah: Jurnal Pendidikan Islam, Vol. 9, No. 1 (2018).

Suci, Yayu Tresna. "Menelaah Teori Vygotsky dan Interdepedensi Sosial sebagai Landasan Teori dalam Pelaksanaan Pembelajaran Kooperatif di Sekolah Dasar". Naturalistic: Jurnal Kajian Penelitan Pendidikan dan Pembelajaran, Vol.3, No.1 (Oktober 2018): 231-239.

Suparno, Paul. Filsafat Konstruktivisme dalam Pendidikan. Yogyakarta: Kanisius, 2006.

Suyanto, Slamet. Dasar-dasar Pendidikan Anak Usia Dini. Yogyakarta : Hikayat, 2005.

Suyudi, M. Pendidikan dalam Perspektif Al-Qur'an. Yogyakarta : Mikraj, 2005.

Syahrodi, Jamali. Membedah Nalar Pendidikan Islam. Yogyakarta: Pustaka Rihlah, 2005.

Tafsir, Ahmad Ilmu Pendidikan dalam Perspektif Islam. Bandung: Remaja Rosdakarya, 1994. 
Tholkhah, Imam dan Barizi, Ahmad. Membuka Jendela Pendidikan. Jakarta: Raja Garfindo Persada, 2004.

Topçiu, Marta. "Vygotsky Theory on Social Interaction and its Influence on the Development of Pre-School Children". European Journal of Social Sciences Education and Research, Vol. 2, No. 3 (MayAugust 2015).

Trianto. Model Pembelajaran Terpadu dalam Teori dan Praktek. Jakarta : Prestasi Pustaka, 2007.

Yusuf, Syamsul. Psikologi Perkembangan Anak dan Remaja. Bandung : Remaja Rosdakarya, 2005. 